\title{
The CCUT block cave design for Cullinan Diamond Mine
}

\author{
by H. Tukker*, A. Holder ${ }^{\dagger}$, B. Swarts ${ }^{\dagger}$, T. van Strijp ${ }^{\dagger}$, and \\ E. Grobler ${ }^{\dagger}$
}

\section{Synopsis}

Petra Diamonds' Cullinan Diamond Mine (CDM) is currently producing from two mining blocks that are nearly depleted and highly diluted. CDM is developing the CCUT mining block as a mechanized block cave with an advance undercut that would replace the current mining blocks and increase production to approximately $4 \mathrm{Mt} / \mathrm{a}$. The CCUT block production level on $839 \mathrm{~m}$ level is approximately $200 \mathrm{~m}$ below the current production areas on the 630 and $645 \mathrm{~m}$ levels.

The planning of the CCUT block with a lift height of approximately $194 \mathrm{~m}$ at CDM under Petra's ownership commenced in 2008. The access declines to the block started in 2009 and 2010. Most of the shaft deepening and waste development have been completed, with the planned 'deep' shaft and ground-handling system planned for commissioning in June 2016. The first undercut ring was blasted in July 2015.

This paper reports on the design process and evolution of the project, including:

> Geotechnical design criteria

> Advance undercutting sequence and strategy

> Undercut advance rates, slot designs, and rings designs to achieve the undercutting objectives (of high early tonnages and high undercut advance rates)

> The production level development philosophy in utilizing advance undercutting, production level design and drawbell opening sequence.

Keywords

block, cave design, advance undercut, rock mass characteristics, support regime. below the sill on elevations $630 \mathrm{mbs}$ and 732 mbs respectively were changed from postundercut panel retreat caves to advance undercut block caves to reduce the tunnel deformation and failures caused by high abutment stresses on the production level infrastructure, which was developed and constructed ahead of the undercut face. The BA5 block cave can be considered a success, with high extractions achieved, especially in the hard western Hypabyssal Kimberlite, albeit with significant tunnel failures in the softer Grey Kimberlite zones close to the contact. The BB1E and AUC mining blocks that lie within the soft eastern Brown and Grey kimberlites respectively experienced massive tunnel failures early in their lives and a recovery level on $747 \mathrm{mbs}$ had to be established to recover the remaining BB1E resource tons (see Figure 2 ).

The mine was renamed Cullinan Diamond Mine (CDM) after the Cullinan Diamond as part of its centenary celebrations in 2003. Petra Diamonds acquired CDM from De Beers in November 2007. Petra initiated mining studies in 2008 to mine the CCUT resource defined down to $1073 \mathrm{mbs}$. Two declines to access the lower CCUT mining block were started in 2009 and 2010.

Historical production from CDM ranged from 2 to $5 \mathrm{Mt} / \mathrm{a}$ ). More than $360 \mathrm{Mt}$ of kimberlite ore have been mined to date over 113 years, yielding approximately 128 million carats at 35 carats per hundred tons (cpht). CDM has produced over 750 stones that are

* Ukwazi Mining Solutions, Johannesburg, South Africa.

$\dagger$ Petra Diamonds Group, Johannesburg, South Africa.

(C) The Southern African Institute of Mining and Metallurgy, 2016. ISSN 2225-6253. This paper was first presented at the Diamonds still Sparkling 2016 Conference, 14-17 March 2016, Gaborone International Convention Centre. 


\section{The CCUT block cave design for Cullinan Diamond Mine}

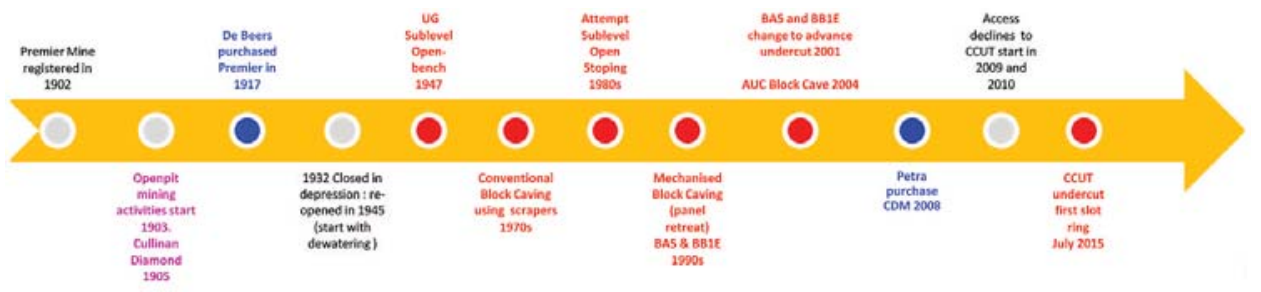

Figure 1-History of Cullinan Diamond Mine (CDM)

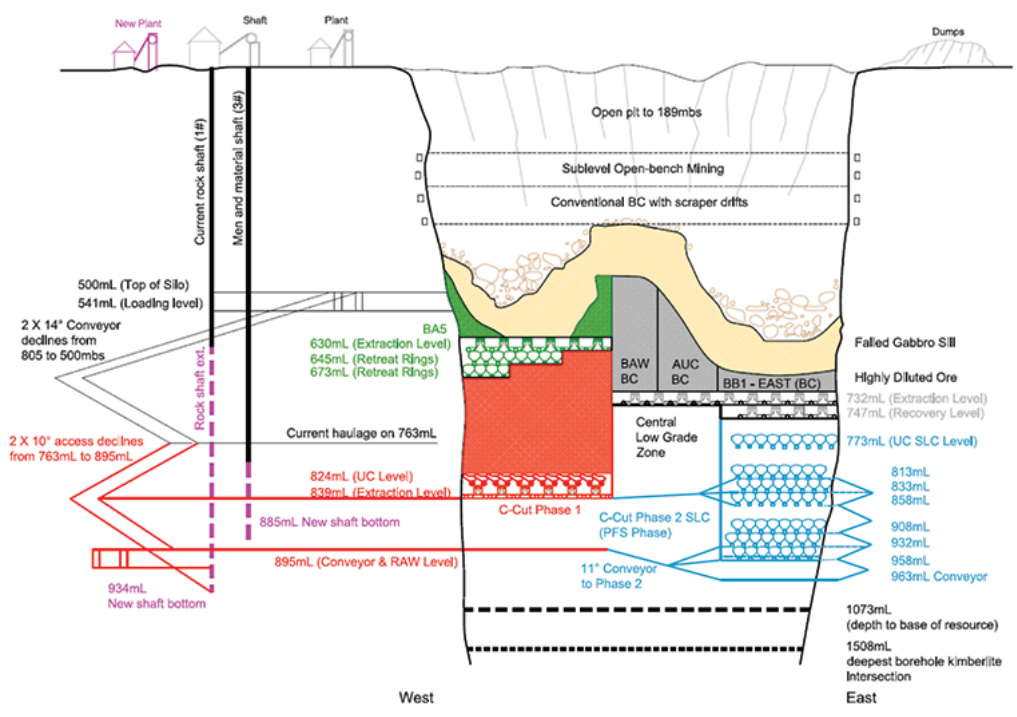

Figure 2-Schematic section of CDM showing mining blocks and infrastructure

greater than 100 carats and more than a quarter of the world's diamonds that are greater than 400 carats in size. It is furthermore also the only significant source of blue diamonds in the world.

Current CDM mine infrastructure includes a rock shaft (No. 1 Shaft) for waste and ore hoisting from $541 \mathrm{~m}$ level $(\mathrm{mL})$ and a men and a material shaft (No. 3 Shaft) that provides access down to $763 \mathrm{~mL}$. Production from underground mining sections is currently from highly diluted block cave drawpoints on $747 \mathrm{~mL}$ and retreat rings on 645, 673 , and $732 \mathrm{~mL}$ at a rate of approximately $2.6 \mathrm{Mt} / \mathrm{a} .645$ and $673 \mathrm{~mL}$ were old ventilation levels for the BA5 block and these levels were converted to longhole retreat production sections to serve as tonnage gap-fillers between the current blocks and the CCUT. $732 \mathrm{~mL}$ was the extraction level for the $\mathrm{BB} 1 \mathrm{E}, \mathrm{AUC}$, and BAW blocks and the remaining production planned from these blocks will be retreat rings recovering the major apex pillars above the old production tunnels. BAW was abandoned due to the low grades reporting from this area.

With the current ground-handling system ore is loaded with load haul dumpers (LHDs) from production section and tipped into rock-passes from where it is trammed with locos and hoppers on $763 \mathrm{~mL}$ to the north and south jaw crushers. The two crushers feed two conveyors positioned on $805 \mathrm{~mL}$ that convey the rock to the top of the No. 1 Shaft silos at $500 \mathrm{~mL}$. The loading level on $541 \mathrm{~mL}$ feeds the No. 1 Shaft loading flasks, from where rock is hoisted to surface. On surface, the ore is conveyed to the processing plant, which was constructed in 1947 but has been continuously modified and upgraded to recover large and small diamonds.

The CCUT project entailed establishing new surface and underground infrastructure to extract the next mining block below the depleted BA5 mining block using block caving with an advance undercut at a production rate of $4 \mathrm{Mt} / \mathrm{a}$. This project required major recapitalization that included:

- Extending the existing shafts to provide access, services, and rock hoisting on the CCUT horizon as shown in Figure 2. This includes two new shaft bottoms, a loading level, pumping infrastructure, underground workshops, and underground stores

> No. 1 Shaft winder upgrade to increase the hoisting capacity to $4 \mathrm{Mt} / \mathrm{a}$ from $934 \mathrm{mbs}$

> Extending two declines down from $763 \mathrm{~mL}$ to the CCUT ground handling level on $895 \mathrm{~mL}$

- A new block cave with undercut level on $824 \mathrm{~mL}$ (measurement from the undercut gives an effective lift height of $194 \mathrm{~m}$ to $630 \mathrm{~mL}$ ), production level on $839 \mathrm{~mL}$, and ground-handling on $895 \mathrm{~mL}$, as shown in Figure 2.

\section{Geology}

The CDM kimberlite pipe has a kidney-shaped exposure on surface and measures $860 \mathrm{~m}$ by $400 \mathrm{~m}$, elongated along a NW-SE axis. The surface area of the pipe is approximately $32 \mathrm{ha}$, decreasing progressively to $22 \mathrm{ha}$ at $500 \mathrm{mbs}$ and 12 ha at 1000 mbs. Subsidence caused by the mining 


\section{The CCUT block cave design for Cullinan Diamond Mine}

operations has increased the surface rim size more than 40 ha. It has been estimated that the top $300 \mathrm{~m}$ of the original pipe has been removed by erosion since its intrusion 1200 million years ago. The diatreme zone of the pipe is fairly unique in that it has been cut by a younger $75 \mathrm{~m}$ thick gabbro sill that dips shallowly from north to south between elevations $350 \mathrm{mbs}$ and $525 \mathrm{mbs}$, as indicated in Figure 3. The country rock around the pipe consists of Waterberg quartzites, felsite, norite, and Transvaal Supergroup metasediments, as shown in Figure 3. Three major kimberlite intrusions have been identified within the pipe. Two of these are typical volcaniclastic kimberlites (previously identified as tuffsitic kimberlite breccia or TKB), while the final phase of intrusion is a hypabyssal kimberlite core complex in which four kimberlite types and late-stage carbonaceous dykes have been identified.

> Brown Kimberlite is a volcaniclastic kimberlite that has the highest clay content and is the weakest kimberlite at CDM. It represents the first intrusion and has the highest grade, which varies from 60-115 carats per hundred tons (cpht). It also contains diamonds with the highest average value

> Grey Kimberlite is also a volcaniclastic kimberlite, and can be classified as weak kimberlite with high clay content. This facies has the lowest grade and lowest value diamonds, especially close to the centre of the pipe where there is significant internal waste (the 'Grey Waste' sub-facies), and grades are estimated to be generally below $30 \mathrm{cpht}$. This area has remained mostly unmined below the sill due to its low payability

> The hypabyssal core is made up of Pale and Dark Piebald hypabyssal kimberlite surrounded by Black and Green transitional kimberlite. It is more competent than the two volcaniclastic kimberlite facies, with almost no clay content. This kimberlite is believed to be responsible for producing the majority of large $(>100 \mathrm{ct})$ stones at CDM, including the Type $2 \mathrm{a}$ and blue boron-bearing Type $2 \mathrm{~b}$ diamonds perceived to occur close to the internal Grey/Hypabyssal and
Grey/Waste contacts on the western side of the pipe. The grade within this facies varies from 30-70 cpht. The project footprint consists mostly of the Hypabyssal Kimberlite core surrounded by Grey Kimberlite, as shown in Figure 4.

The late-stage carbonaceous kimberlite dykes at CDM are widespread and intrude into all kimberlite facies. In some cases where these dykes occur parallel to, or on, internal facies contacts and close to pipe contacts they can cause major instability in the form of shear planes that can fail uncontrollably if not supported timeously and correctly during the development phase.

\section{Geotechnical setting and design parameters}

Table I indicates the rock mass characteristics for the project area at CDM. Note that the uniaxial compressive strength (UCS) and the mining rock mass rating (MRMR) values for the Grey and Hypabyssal kimberlites have large ranges, and the average values indicate that the ground for the CCUT project should be fairly competent with minimal expected
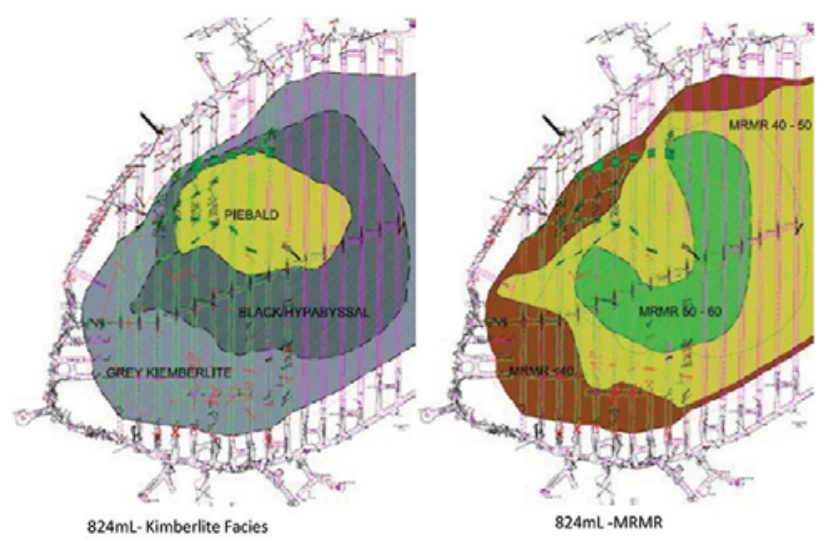

Figure 4-Kimberlite facies and the MRMR interpretation for the undercut level $(824 \mathrm{~mL})$

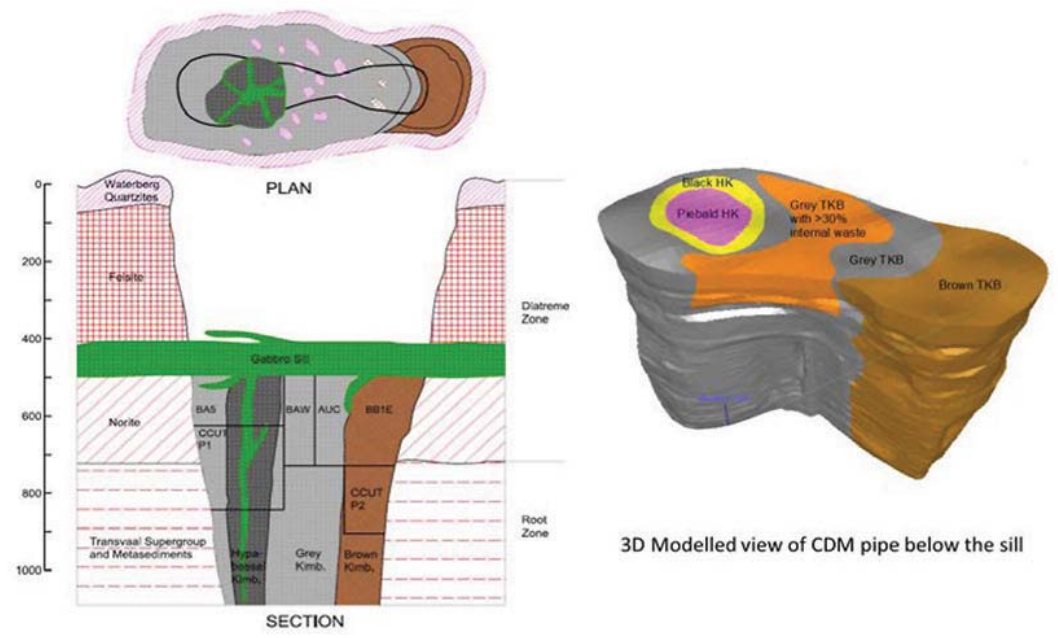

Figure 3-Plan and section of the generalized geology of the CDM pipe below the sill (after Bartlett and Kroll, 2000), and 3D geological interpretation of the pipe 


\section{The CCUT block cave design for Cullinan Diamond Mine}

\begin{tabular}{|c|c|}
\hline \multicolumn{2}{|c|}{$\begin{array}{l}\text { Table I } \\
\text { Rock mass characteristics at CDM relevant to } \\
\text { CCUT }\end{array}$} \\
\hline Rock classification & Value \\
\hline Kimberlite density (SG) & $\begin{array}{l}2.66 \text { Grey } \\
2.71 \text { Hypabyssal }\end{array}$ \\
\hline Country rock density (SG) & $\begin{array}{l}2.85 \text { Norite } \\
\text { 2.65 Metasediments }\end{array}$ \\
\hline Av. UCS of kimberlite (MPa) & $\begin{array}{l}\text { 80-130 Grey } \\
\text { 73-193 Hypabyssal }\end{array}$ \\
\hline Av. UCS country rock (MPa) & $\begin{array}{l}\text { 140-220 Norite } \\
60-240 \text { Metasediments }\end{array}$ \\
\hline Mining rock mass rating & $\begin{array}{l}30-50 \text { (Grey) and } 25-35 \text { (at contacts, } \\
\text { some internal dykes and shear zones) } \\
40-60 \text { (Hypabyssal) }\end{array}$ \\
\hline Hydraulic radius & $\begin{array}{l}\text { BA5 above CCUT caved at } 30 \text {, but the } \\
\text { CCUT undercut is started in the weak } \\
\text { Grey Kimberlite. Expected HR between } \\
20 \text { and } 25 \text { for average MRMR of } 35\end{array}$ \\
\hline
\end{tabular}

problems. The localized weak mining zones with lower-end MRMRs close to the pipe and internal contacts as shown in Figure 3 do, however, suggest that ground conditions pose a significant geotechnical risk if not managed properly, as experienced in the BA5 directly above the CCUT. The current generic tunnel support regime for the CCUT block includes bolts, sealant, welded mesh, and shotcrete. The contacts and drawpoints will have site-specific recommendations, usually including stiff brow steel sets.

Figure 4 shows that the weaker (lower MRMR) areas are generally close to the contact zones, with the hypabyssal core being competent. All the undercut and production tunnels intersect the contact or weaker zones and the mine design, sequence, and tunnel support standards have to ensure that these areas stay open for the life of the production block. With this in mind a back-analysis was done on the AUC block cave, which is located in the Grey Kimberlite as shown in Figure 3. This block sat down halfway through the undercutting process and most of the undercut tunnels crushed within a short space of time. The process entailed simulating the mining steps that were followed in a geotechnical modelling package and calibrating the model until the results replicated the actual events that followed.
The model was then re-calibrated for CCUT conditions, including rock characteristics depth, pipe geometry etc. Different scenarios were designed, sequenced, and modelled to achieve the optimal outcome. Some of the model outcomes at different stages of undercutting and production drawbell construction are shown in Figure 5.

This paper does not report on the specifics of the geotechnical modelling, which are covered elsewhere, but focuses on the recommendations incorporated into mine design and schedule. The geotechnical recommendations were as follows:

> The undercut tunnels were sized to $4 \mathrm{~m}$ wide and $4 \mathrm{~m}$ high and the extraction level development to $4.2 \mathrm{~m}$ wide by $4.2 \mathrm{~m}$ high

> The El Teniente layout was chosen as the preferred block cave layout as this resulted in improved development efficiencies and quality while reducing the planned drawbell construction and opening times compared to the herringbone layout

> The undercut tunnel spacing of $16 \mathrm{~m}$ and production tunnel spacing of $32 \mathrm{~m}$ used in the modelling were found to be appropriate

> The extraction level drawpoint spacing of $16 \mathrm{~m}$ had to be increased to $18 \mathrm{~m}$. It was furthermore recommended that the spacing be increased to $21 \mathrm{~m}$ for the last third of the footprint to avoid the deformation shown in Figure 5. Local underground observations will, however, guide geotechnical simulations and subsequent recommendations going forward

> The analysis shows that the undercut deformation was normal until undercutting was around 65-75\% complete. The final corner showed significant levels of deformation due to the pipe geometry. Wrecking of the final problematic undercut zone might be an appropriate strategy, but observations going forward will dictate the final recommendations

> The southern contact appears to be problematic with fringing occurring (see Figure 5). The presence of a local shear zone is another complication that might amplify the problems highlighted by the modelling

> The initial undercut strategy, consisting of an advance undercut with production drifts and drawpoint stubs ahead of the undercut face, was revised to having only the first four tunnels (without any stubs) developed

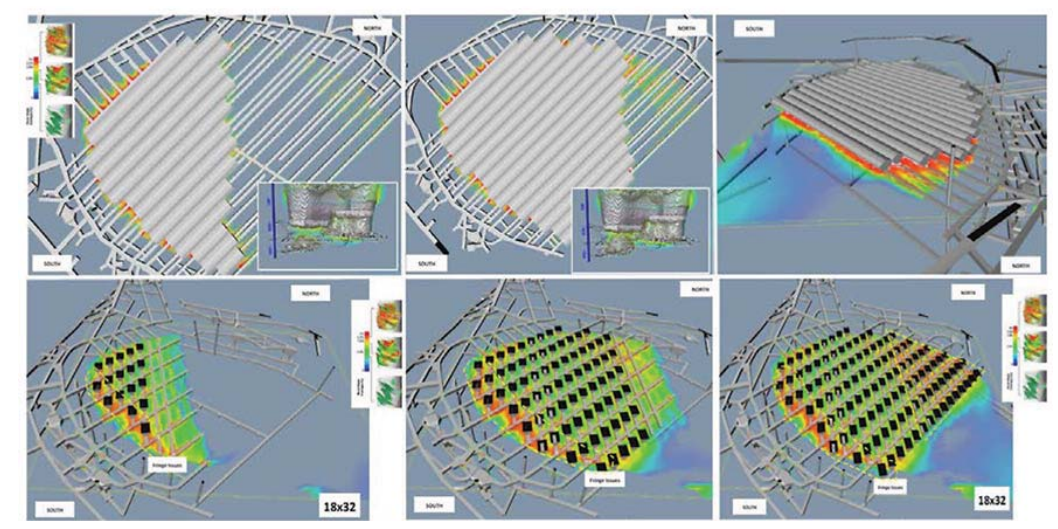

Figure 5-Geotechnical modelling outputs for different steps in mining sequence, damage shown as expected deformation (source: Beck Engineering) 


\section{The CCUT block cave design for Cullinan Diamond Mine}

ahead of the undercut face. Of the remaining four tunnels, only every second tunnel can be developed ahead of the undercut

> Local ground conditions must be re-interpreted continuously and the mine design and sequence adapted accordingly.

\section{Underground infrastructure}

The CCUT project consists of three major levels: an undercut, production, and conveyor/ventilation (RAW) level. The main underground infrastructure entails:

> Ground handling (see Figure 6 to Figure 8):

- $13 \times 9 \mathrm{t}$ LHDs $(100 \mathrm{t} / \mathrm{h}$ or $33333 \mathrm{t} /$ month per
LHD) loading from development, rings, rim loading, and production level drawpoints. Total capacity of 13 LHDs is $5.2 \mathrm{Mt} / \mathrm{a}$

- Undercut level: $4 \times$ tips with $600 \mathrm{~mm}$ grizzly, rockbreaker, and orepass configuration, each feeding one of four crushers

- Production level: $4 \times$ double-tip $600 \mathrm{~mm}$ grizzly, rockbreaker, and orepass configuration, each feeding one of four crushers

- $4 \times 450 \mathrm{t} / \mathrm{h}$ (100 kt/month or $1.2 \mathrm{Mt} / \mathrm{a}$ each) jaw crushers positioned below the production level. Enough space was allowed above the crushers to introduce a recovery level if required without changing the ground-handling system materially

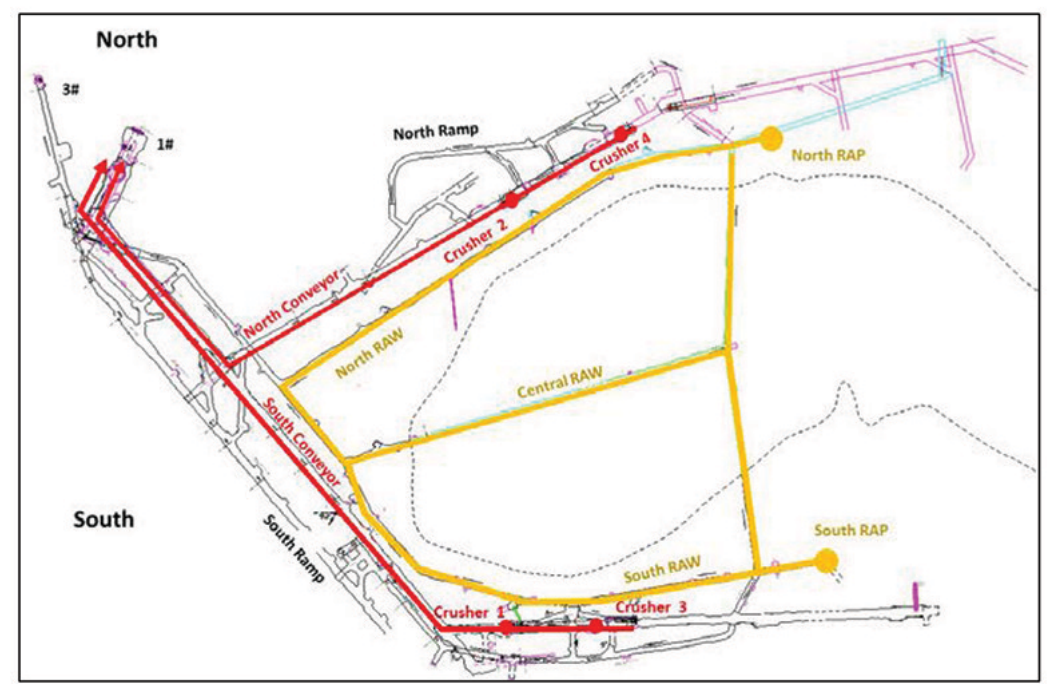

Figure 6-895 mL conveyor and RAW level with crusher excavations

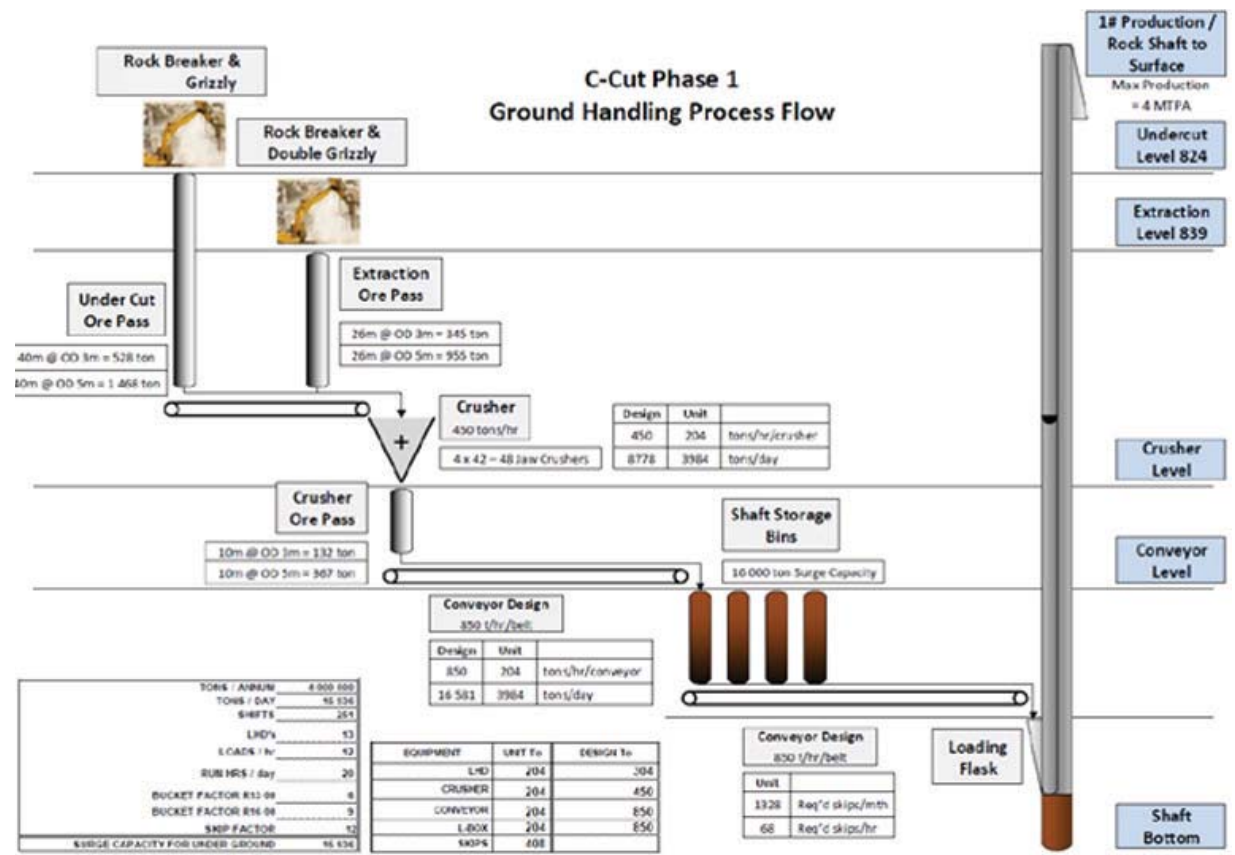




\section{The CCUT block cave design for Cullinan Diamond Mine}
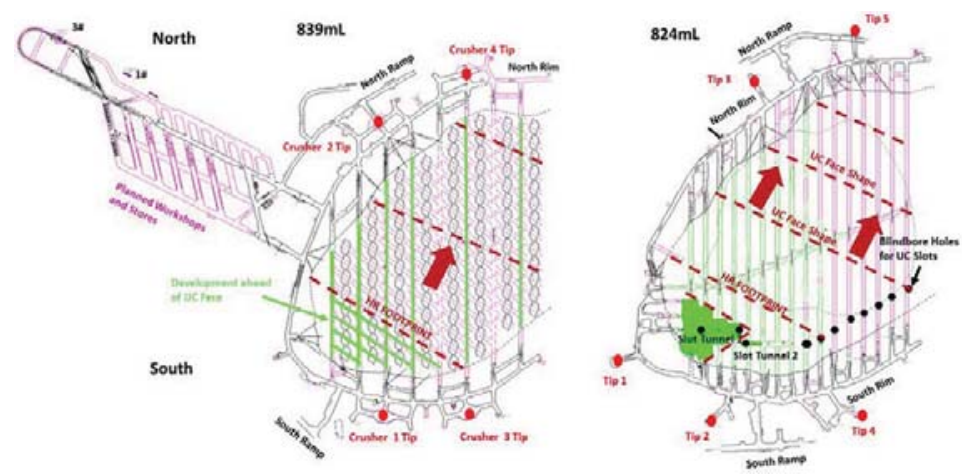

Figure $8-839 \mathrm{~mL}$ production level (left) and $824 \mathrm{~mL}$ undercut level (right)

- $2 \times 1200 \mathrm{~mm}$ strike conveyors $(850 \mathrm{t} / \mathrm{h}$ or 3.6 $\mathrm{Mt} / \mathrm{a}$ each) below the crushers convey the ore to the new shafts silos

- The No. 1 Shaft hoisting capacity of $4 \mathrm{Mt} / \mathrm{a}$ is the limiting factor on the ground-handling configuration

> Ventilation (see Figure 6 and Figure 8):

- The shafts and declines accessing the block facilitate air intake for the mining section. The dirty production air is directed from the production tunnels down raisebore holes to the return airway level (RAW level) on $895 \mathrm{~mL}$. The dirty air in the RAW is then directed to the central return airpasses (RAPs) that link into the main mine returns

> Trackless maintenance and shaft logistics (see Figure 8):

- Temporary workshops constructed on $763 \mathrm{~mL}$ will serve until the new centralized workshop on $839 \mathrm{~mL}$ has been developed and equipped

- All the material will be dispatched via No. 3 Shaft to the $839 \mathrm{~mL}$ laydown area and store facility, from where it will be issued to mining crews

- Production personnel will access the production level via No. 3 Shaft on $839 \mathrm{~mL}$

\section{Undercut design and schedule}

The weakest zone within the project area is the southwestern zone, as shown in Figure 4, with MRMR ratings below 40 and in some instances 30-35. The hydraulic radius (HR) for the area is estimated to be $20-25 \mathrm{~m}$. In assessing the overall risk of undercutting the entire footprint, the decision was taken to initiate the undercut slot in the southwest to ensure that the higher risk area was undercut before the HR with associated high abutment stresses was reached. Initiating the undercut in the weaker ground would also allow for higher initial cave propagation and production rates. The undercut slot tunnel was positioned $30 \mathrm{~m}$ from the southwest contact to enable high undercutting rates towards the south and north to reach the HR footprint within the first nine months of undercutting, and by doing so reach the more competent zones early in the undercutting process as shown in Figure 9. The undercut face shape can be described as diagonal, with 6-8 $\mathrm{m}$ lead-lags being maintained while the face advances in a northeast direction. The lead-lags will also be adjusted in response to local ground conditions observed, especially close to shear zones, tunnel intersections, internal contacts, and pipe contacts. The rings advancing to the southern contact were initially planned to have a height of $12 \mathrm{~m}$. However, to improve stability close to the contacts and to increase production capability, being close to the south tips, the required undercut height was increased from $12 \mathrm{~m}$ to $20 \mathrm{~m}$ on the south of the slot tunnel. The ring height on the northern side was reduced to $6 \mathrm{~m}$, as shown in Figure 10, for the following reasons:

> Required longhole drilling metres: only $75 \mathrm{~m}$ per ring allows for quick drilling turnaround time

- Low probability of pillars with a low undercut and ease of ability to fix potential problems, i.e. large rings big problems and small rings small problems'

> Tonnage per ring reduced from almost $1500 \mathrm{t}$ to approximately $500 \mathrm{t}$ in situ considering the long tramming distance to the northern tips

> Low logistical requirements enabling high advance rates.

The average monthly required undercut advance rate is four rings (or $8 \mathrm{~m}$ ) and the total output for the undercut per month is 48 rings, $1400-1800 \mathrm{~m} 2,17000 \mathrm{t}$ (at 60-70\% draw of blasted tons), and approximately 4000 longhole metres with $10 \%$ re-drill. The powder factor using bulk emulsion is $0.75-1.0 \mathrm{~kg} / \mathrm{t}$ for the undercut rings $(2 \mathrm{~m}$ burden, $2-2.3 \mathrm{~m}$ toe spacing using $76 \mathrm{~mm}$ blast-holes).

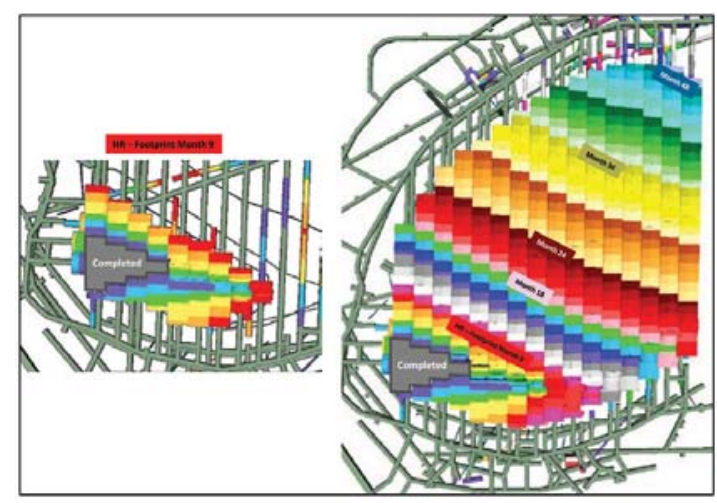

Figure 9-Undercut level sequence as planned in Mine2-4D - HR is reached in month 9 


\section{The CCUT block cave design for Cullinan Diamond Mine}

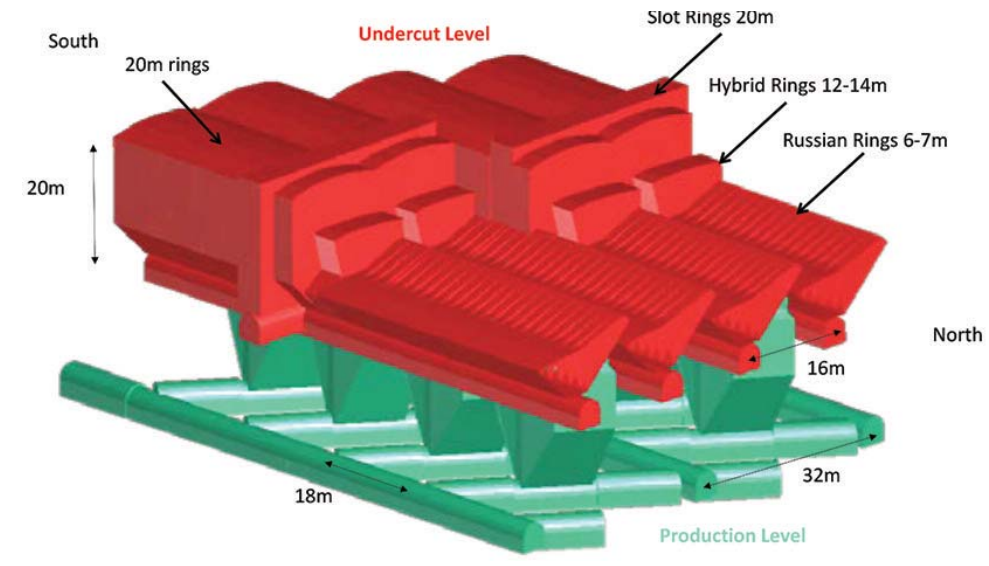

Figure 10-Undercut and production level model with ring configuration

\section{Production level design and schedule}

The production level has a tunnel spacing of $32 \mathrm{~m}$ and a drawpoint spacing of $18 \mathrm{~m}$ as shown in Figure 11. The production level construction strategy employed at the CCUT project entails constructing the drawbells within the HR footprint ahead of the undercut face, which includes the first 4 bell rows or 10 drawbells in total, while the abutment stresses are considered to be low.

The remaining footprint will be constructed as an advance undercut that entails constructing only tunnels $1-4,6$, and 8 ahead of the undercut face and all the other drawbells and tunnels 5 and 7 in the de-stress shadow of the undercut face, as shown in Figure 8, to avoid abutment stresses damaging production level infrastructure. The re-compaction time guideline used in determining the construction cycles and resource requirements is 6 months, which is the time to open up a drawbell from the time the undercut advances over the area. Two months is required for the undercut moving at $8 \mathrm{~m}$ per month $(16 \mathrm{~m})$ to create the de-stress shadow, and another four months for development and construction (see Figure 12). If this timeline is not adhered to and the undercut runs away from the production level, the area already undercut might re-compact and the abutment stresses reconfigure over these zones and be transmitted down onto the production level.

The training of the production level construction crews entails using the initial 10 drawbells inside the HR boundary as a school to acquire the appropriate skills to complete the required activities within a set sequence and timeframe. The activities include development, tunnel support, placement of footwall concrete, construction of stiff-brow sets, blindboring, longhole drilling, longhole charging, and production loading as shown in Table II. Most of these activities must occur within the space of one month in a production tunnel.

The individual activities and durations allowed for are not difficult to achieve, but the combination of all the required activities in a set sequence in one tunnel makes the scheduling extremely complex, rigid, and difficult to achieve. In an advance undercut scenario the emphasis is on tunnel utilization and not necessarily resource utilization or efficiency, which means that the activities have to be overresourced at lower efficiencies to ensure that the required cycle is achieved. CDM has opted for a 5-day three-shift configuration and has populated its micro-schedules according to this shift configuration. This shift arrangement equates to 62 available shifts, an average of 1.5 activities per
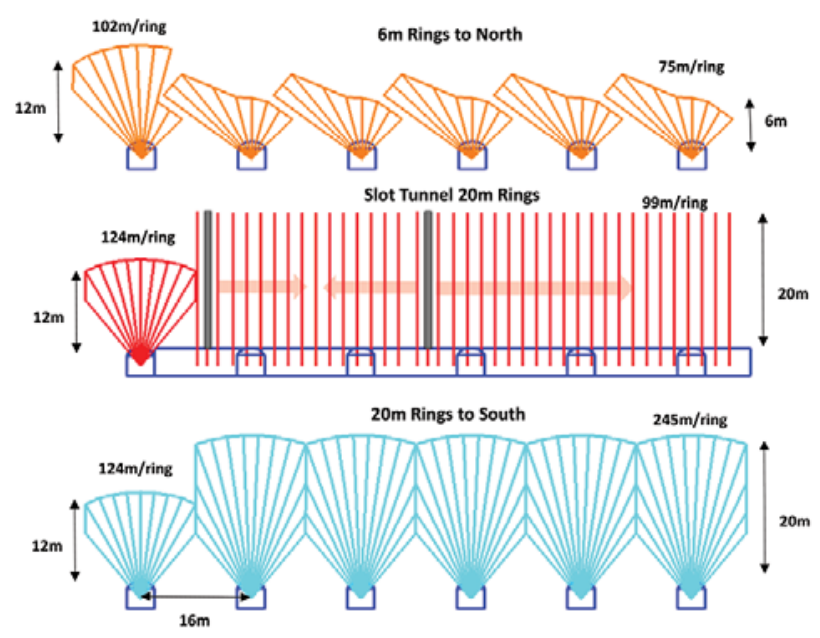

Figure 11-Generic ring designs for the undercut level

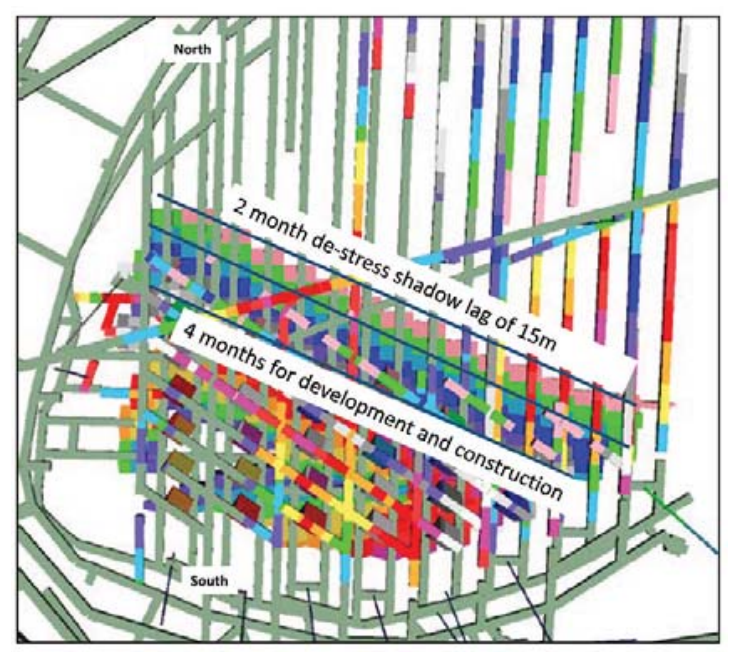

Figure 12-View from below looking up at the production and undercut level leading by 6 months 


\section{The CCUT block cave design for Cullinan Diamond Mine}

\begin{tabular}{|c|c|c|c|}
\hline \multicolumn{4}{|c|}{$\begin{array}{l}\text { Table II } \\
\text { Production level construction activities to establish three drawbells per month }\end{array}$} \\
\hline Activity & Total block & Per production tunnel or access & Time per activity per tunnel \\
\hline Development & $80-100 \mathrm{~m} / \mathrm{month}$ & $15-20 \mathrm{~m} /$ month & 10 shifts \\
\hline Tunnel support & $80-100 \mathrm{~m} / \mathrm{month}$ & $15-20 \mathrm{~m} / \mathrm{month}$ & 10 shifts \\
\hline Footwall concrete & $60-80 \mathrm{~m} / \mathrm{month}$ & $12-15 \mathrm{~m} / \mathrm{month}$ & 5 shifts \\
\hline Stiff-brow drawpoint sets & $6 \times$ sets & 1 set & 10 shifts \\
\hline Blindbore metres & $3 \times 25 \mathrm{~m}$ holes & 0.5 holes $-12.5 \mathrm{~m}$ & 6 shifts \\
\hline Longhole drilling & $3 \times$ drawbells at $1200 \mathrm{~m} / \mathrm{bell}=3600 \mathrm{~m} / \mathrm{month}$ & 0.5 bells $-600 \mathrm{~m}$ & 6 shifts \\
\hline Longhole dharging & $\begin{array}{c}3 \times \text { drawbells at } 3 \text { blasts per bell }=9 \text { blasts } \\
27 \text { drawbell rings }\end{array}$ & 0.5 bells -2 blasts & 2 shifts \\
\hline Production doading & All open drawpoints & Minimum 1 shift per day per tunnel & 20 shifts \\
\hline Time required in tunnel & & $\begin{array}{l}69 \text { shifts (single activity in the tunnel } \\
35 \text { shifts (two activities in the tunnel) }\end{array}$ & \\
\hline Redundancy & & $20 \%$ & \\
\hline Total time required in a tunnel & & $\begin{array}{l}83 \text { shifts (single activity in the tunnel) } \\
42 \text { shifts (two activities in the tunnel) }\end{array}$ & \\
\hline Time available & & $\begin{array}{l}5 \text { days, } 2 \text { shifts/day }-41 \text { shifts } \\
5 \text { days, } 3 \text { shifts/day }-62 \text { shifts } \\
11 \text { days, } 2 \text { shifts/day }-46 \text { shifts } \\
11 \text { days, } 3 \text { shifts/day }-69 \text { shifts } \\
\text { FULCO } \times 3 \text { shifts/day }-90 \text { shifts }\end{array}$ & \\
\hline
\end{tabular}

tunnel (with the focus on getting the ventilation in place to allow multiple activities in a tunnel, not all the activities can be carried out in parallel), and overtime to recover any slip in the schedule. The first 6 months will serve as a trial, and if required the CCUT crews can convert to a FULCO shift configuration as a last resort to ensure that the schedule is achieved.

\section{Production level drawpoint maturity rules}

The expected fragmentation for the CCUT is $30 \%>2 \mathrm{~m}^{3}$ (oversize) initially and $7-12 \%>2 \mathrm{~m}^{3}$ after $20 \%$ draw. The maturity rules have been adjusted to allow for lower initial draw rates in the build-up and higher rates on reaching maturity to avoid excessive percentages of oversize that must be blasted or handled by the the grizzly. The drawpoint maturity rules as applied in mining scheduling software packages (Mine2-4D and PCBC) can be viewed in Table III. A total of 184 drawpoints will be in production at steady-state, allowing for sufficient redundancy when producing at a rate of $4 \mathrm{Mt} / \mathrm{a}$.

\section{Conclusion}

CDM's CCUT block cave will be one of the deepest mechanized kimberlite block caves in production when it reaches steady state at $4 \mathrm{Mt} / \mathrm{a}$ in three years' time. The first undercut rings were blasted in July 2015 and the first drawbell will be opened in January 2016. The fundamentals of the mine design and schedule seem appropriate thus far, with development and ring blasting being on schedule, although problems were encountered in handling waste tonnage and getting the ventilation infrastructure in place. Future planning at CDM entails implementing more detailed micro-schedules in the production level construction environment to ensure that timetables are achieved on an hour-by-hour, day-by-day, and month-to-month basis. Up-
Table III

CCUT drawpoint maturity rules

\begin{tabular}{|l|c|c|c|}
\hline $\begin{array}{l}\text { Drawpoint age } \\
\text { (months) }\end{array}$ & $\begin{array}{c}\text { Accumulated } \\
\text { mined (t) }\end{array}$ & $\begin{array}{c}\text { Max. } \\
\text { capacity (t/d) }\end{array}$ & $\begin{array}{c}\text { Max. draw } \\
\text { (mm/d) }\end{array}$ \\
\hline 0 & 0 & 50 & 71 \\
3 & 3000 & 75 & 107 \\
6 & 7500 & 100 & 142 \\
12 & 19500 & 155 & 220 \\
\hline
\end{tabular}

skilling and build-up of specialized longhole, development, and construction crews is also a priority to ensure that the production level targets are achieved, thereby ensuring the successful tonnage ramp-up of the CCUT block.

\section{Acknowledgements}

The authors thank Petra Diamonds for allowing us to publish this paper, and in particular the CCUT project team at CDM. Contributions and technical input were provided by Andrew Rogers.

\section{References}

Bartlett, P.J. and Croll, A. 2000. Cave mining at Premier Diamond Mine. Proceedings of Massmin 2000, Brisbane, Queensland, 29 October - 2 November 2000. Australasian Institute of Mining Metallurgy, Melbourne. pp. 227-235.

BECK, D. 2010. Premier Mine Stability 824/839 Level.

BECK, D. 2014. Assessment of stability of proposed designs for CCUT Phase 1 and 2 .

LAUBSCHER, D.H. 1994. Cave mining - the state of the art. Journal of the South African Institute of Mining and Metallurgy, vol. 94, October. pp. 279-293

Marsden, H. 2006. Observations of damage in the AUC undercut, Premier Mine. 